\title{
Assessment of vitamin D Concentration and Many Biochemical Parameters in Irritable Bowel Syndrome Patients in Kirkuk City
}

\author{
Fatema Mustafa Ali ${ }^{1}$, Wedad M. Lahmood Al-obaidi ${ }^{2}$ and Abdul-Haleem Salem Al-Tamimi ${ }^{3}$ \\ ${ }^{1,2}$ Department of Biology, College of science, Tikrit University, Iraq and ${ }^{3}$ Department of Biology, College of applied \\ sciences, Thamar University, Yemen. \\ E. mail: haleem2ye@yahoo.com
}

\begin{abstract}
The present study was designed to show the correlation between Irritable Bowel Syndrome (IBS) and vitamin D concentration. 40 patients who had irritable bowel syndrome (IBS) and in addition to 20 blood samples for healthy people with age: 25-65 years, blood samples were collected from Kirkuk General Hospital from March 2016 to December 2016. The results of present study detects significant decreased $(\mathrm{P}<0.05)$ in Vitamin D concentration in irritable bowel syndrome group compare with apparently healthy. Lipid profile (cholesterol, triglyceride, LDL and VLDL has been increased, whereas HDL decreased, the patients suffering IBS show significant increasing $(\mathrm{P}<0.05)$ in malondialdyhyd while GSH showed decreased compare with apparently healthy. It has concluded that the Irritable Bowel Syndrome (IBS) lead to significant changes $(\mathrm{P}<0.05)$ in vitamin $\mathrm{D}$ concentration and biochemical parameters.
\end{abstract}

Keywords: Irritable Bowel Syndrome (IBS); vitamin D; Lipid profile; Oxidative stress.

\section{Introduction}

Irritable bowel syndrome (IBS) is a major cause of abdominal pain and gut disorders. The universal spread of irritable bowel syndrome is proximately to be between $10 \%$ and $20 \%$ of the adult population ${ }^{[1]}$, which shows IBS to be the major frequent diagnosis in gastroenterology ${ }^{[2]}$. A person with Irritable bowel syndrome is typically disordered by abdominal pain or and altered bowel movements (diarrhea and constipation).
Other problems are flatulence, bloating, urgency to defecate, a sense of incomplete evacuation of the bowel, early satiety, and sometimes nausea ${ }^{[1]}$. People with Irritable bowel syndrome represent $20-50 \%$ of all patients in gastroenterology care, and in primary care they represent $12 \%$ of all health care seekers ${ }^{[3,4]}$. Research has looked into vitamin D's potential involvement with disease pathogenesis, severity and perhaps treatment ${ }^{[3,5]}$. Vitamin D deficiency is a 
global epidemic and has been a parallel change in the human intestinal microbiome thought to be linked to the increasing incidence of obesity, hypertension, high cholesterol, autoimmune disorders, and atherosclerotic heart disease ${ }^{[6,8]}$. So the aim is study the level of vitamin D and lipid profile in irritable bowel syndrome patients.

\section{Materials and Methods}

\subsection{Subjects}

This study was conducted in Kirkuk General Hospital on 80 patients who had irritable bowel syndrome (IBS) and in addition to 40 blood samples from healthy people starting from July 2016 to December 2016. The clinical status of patients have been diagnosed by doctors specialized in digestive tract department. The questionnaires of patients have been filled in for every patients their ages ranged from (25 to 65) years.

\subsection{Experimental design}

60 subjects (40 with irritable bowel syndrome and 20 without irritable bowel syndrome) were divided as following:

* Group 1: It included a total of 40 patients (males); their ages ranged from (25-65) years. All patients are suffering from Irritable bowel syndrome.

* Group 2: This group was include 20 apparently healthy subjects as control group (males), and their ages ranged from (25 to 65$)$ years.

\subsection{Sample collections}

$5 \mathrm{ml}$ of blood were collected from the antecubital vein from patients and healthy volunteers and kept in plain tubes. After allowing the blood to clot at room temperature for $15 \mathrm{~min}$, blood samples were centrifuged at $2500 \mathrm{rmp}$ for $15 \mathrm{~min}$. Serum were separated, divided into aliquots and frozen at $-4 \quad C^{\circ}$ for estimation the concentrations of vitamin D and lipid profile.

\subsection{Statistical analysis}

The results of present study were analyzed statistically by using the test of Variance (ANOVA), in order to evaluate the variability significance between patients and healthy groups. The means of data were compared using Duncan's Multiple Range test [9]. 


\section{Results \& Discussion}

\subsection{Vitamin D concentration}

Vitamin D in irritable bowel syndrome group $(11.7 \pm 3.4)$ show significant decreased $(\mathrm{P}<0.05)$ compare with apparently healthy (22.67 \pm 7.12$)$ (fig: 1).

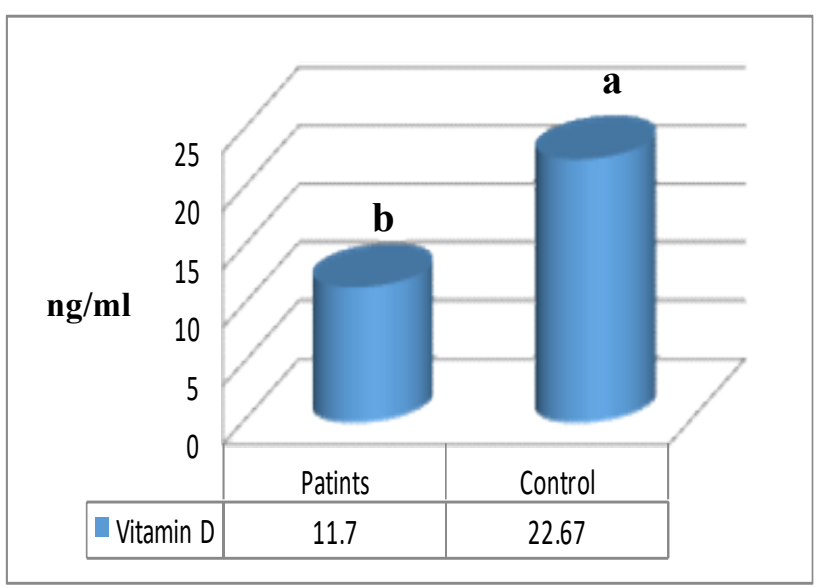

Figure (1): Vitamin D levels in patients and healthy men groups.

The areas of the gut involved in vitamin D absorption is centered predominantly in the ileum $(70-80 \%)^{[10]}$, with most of the vitamin $\mathrm{D}$ receptors and regulatory mechanisms in the cecum and colon regions, the importance of vitamin $\mathrm{D}$ deficiency needs to be addressed seriously in IBS patients as well ${ }^{[11,12]}$. Nwosu et al. (2017) referred to the correlation between IBS and vitamin D level. In their study, IBS subjects had significantly lower mean $25(\mathrm{OH}) \quad \mathrm{D}: 53.2 \pm 15.8 \mathrm{nmol} / \mathrm{L}$ compare with control group $65.2 \pm 28.0$ $\mathrm{nmol} / \mathrm{L}$. they suggest that a high prevalence of vitamin D deficiency in IBS may due to a combination of factors such as restricted food choices, lifestyle habits that limit exposure to sunshine, and the possible role of hypoalbuminemia ${ }^{[13]}$. Also, In study of Khayyat and Suzan (2015) referred that the mean serum level of total $25(\mathrm{OH}) \mathrm{D}$ in IBS patients was $21+12 \mathrm{nmol} / \mathrm{L}$ compared to the control group $31+16 \mathrm{nmol} / \mathrm{L}$. then, the frequency of vitamin D deficiency was found to be high in the IBS group (82\%) and a significant negative correlation between IBS and vitamin D level was found ${ }^{[14]}$.

\subsection{Lipid profile}

Total cholesterol in irritable bowel syndrome group $(252.26 \pm 49.36)$ show significant increased $(\mathrm{P}<0.05)$ compare with apparently healthy (134.54 \pm 27.38$)$ (fig: 2 ).

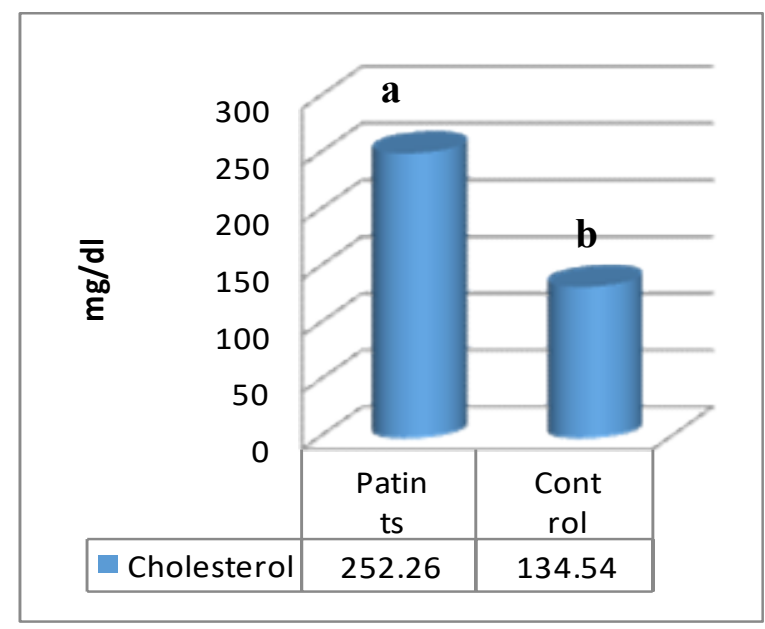

Figure (2): total cholesterol levels in patients and healthy men groups. 
Also, Triglyceride levels show significant increased $(\mathrm{P}<0.05)$ in irritable bowel syndrome group $(220.29 \pm 14.96)$ compare with apparently healthy $(79.27 \pm 13.87)$ as show in (fig: 3 ).

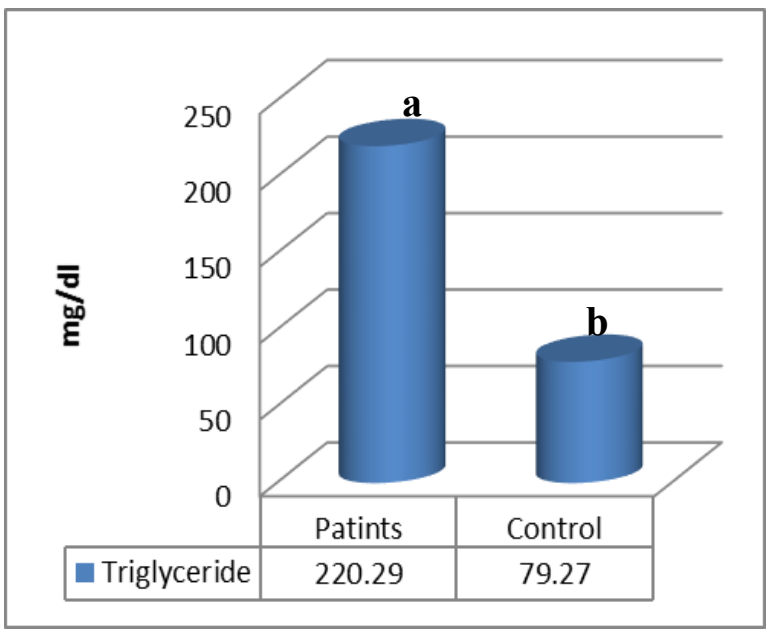

Figure (3): Triglyceride levels in patients and healthy men groups.

HDL in irritable bowel syndrome group $(25.66 \pm 7.89)$ show significant decreased $(\mathrm{P}<0.05)$ compare with apparently healthy (44.01 \pm 6.53) (fig: 4). While, LDL levels show significant increased $(\mathrm{P}<0.05)$ in irritable bowel syndrome group (135.29 \pm 43.36) compare with apparently healthy (74.69 \pm 8.1) (fig: 5). VLDL levels show significant increased $(\mathrm{P}<0.05)$ in irritable bowel syndrome group (46.17 \pm 9.06) compare with apparently healthy (21.6 \pm 6.07) (fig: 6).

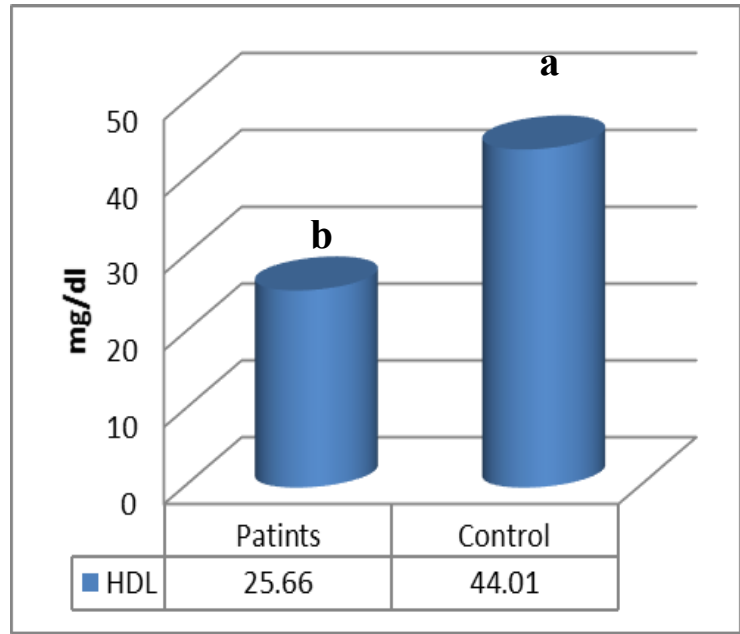

Figure (4): HDL levels in patients and healthy men groups.

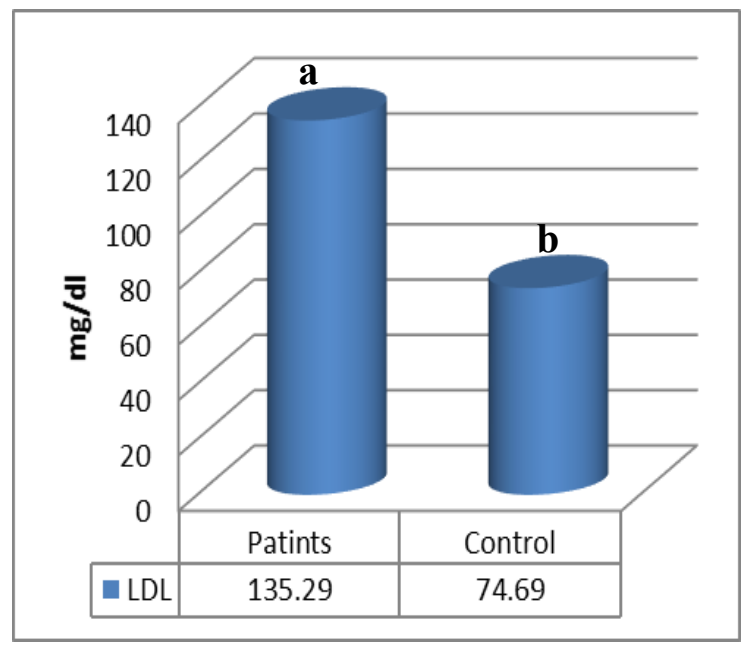

Figure (5): LDL levels in patients and healthy men groups.

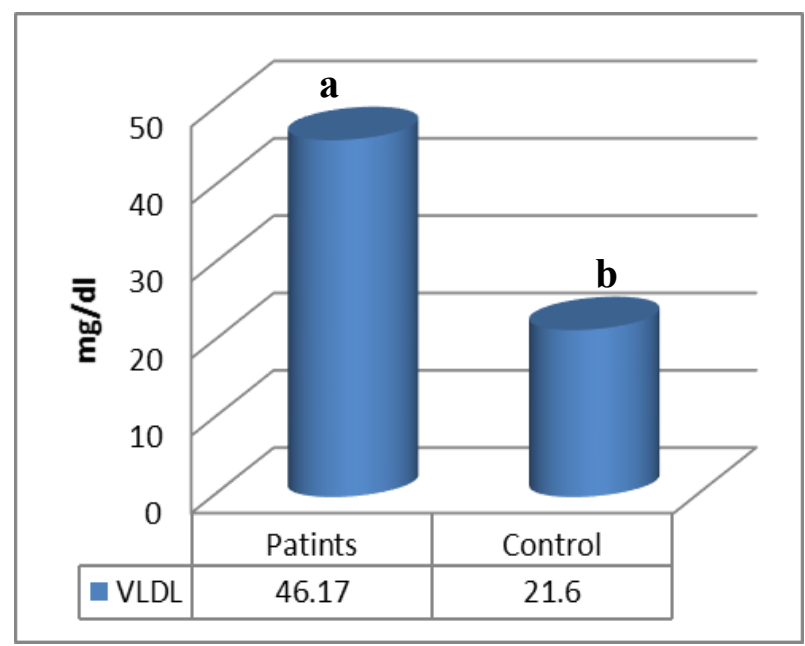

Figure (6): VLDL levels in patients and healthy men groups. 
In higher BMI, the production of the dermal 7- dehydrocholesterol is not altered, but fat tissue might modify its discharge from the skin into the systemic circulation. So, even though it is formed in the skin, vitamin D will remain as a deposit and will not reach the next passages to be further metabolized, but only to a lesser degree than in normal weighted individuals [15]. In study of Steger (2013) which designed to show the association between vitamin D status and blood lipid parameters. The lipid profile levels in pateints with vaitamin D less $20 \mathrm{ng} / \mathrm{ml}$ showed increased in the cholesterol $(217.4 \mathrm{mg} / \mathrm{dl})$, triglyceride $(130.4 \mathrm{mg} / \mathrm{dl})$ and LDL (131.2 $\mathrm{mg} / \mathrm{dl}$ ) with decreased of HDL levels (47.2 $\mathrm{mg} / \mathrm{dl}$ ), that is in agreement with results of present study ${ }^{[16]}$.

Ponda et al (2012) analysis of vitamin D levels and serum lipids in a large clinical laboratory database found modest yet favorable differences between $25(\mathrm{OH}), \mathrm{D}$ levels and total cholesterol (TC), LDL, HDL, and triglyceride (TG). They found increased in the levels of TC, LDL, TG and decreased in HDL levels with vitamin D deficiency pateints ${ }^{[17]}$.

In opposite studies that designed to show the relationship between increased in vitamin
D and lipid profile. Spring (2016) study the relation between vitamin $\mathrm{D}$ and lipid profile. The results show that a higher level of serum $25(\mathrm{OH}) \mathrm{D}$ in the blood was associated with a reduced risk of developing LDLdyslipidaemia, a less reduction in HDL-C, and a less increase in TC-HDL ratio. The mechanisms by which vitamin D may influence lipid levels are uncertain and not well documented ${ }^{[18]}$. However some suggested mechanisms might be that vitamin D by itself or by suppressing the secretion of parathyroid hormone (PTH) to increase lipolysis [19], and thereby increase the breakdown of lipids. Other suggestions are the increase in calcium levels caused by elevated vitamin D levels, which may lead to a reduction in TG levels ${ }^{[20]}$. Lipid profile (cholesterol, triglyceride, LDL and VLDL) were increased when the vitamin D levels deceased. HDL show positive correlation with vitamin D deficiency. In several study showed the concentrations of serum $25(\mathrm{OH}) \mathrm{D}$ are lower than those in normal weighted subjects [21, 23]. McGill et al. (2008) referred that the higher the BMI and waist circumference, the lower $25(\mathrm{OH})$ D concentrations in a New Zealand obese population ${ }^{[24]}$. An American study found similar results in the obese participants; the $25(\mathrm{OH}) \mathrm{D}$ values were 
systematically lower in obese than in their normal weight counterparts ${ }^{[25]}$.

\subsection{Oxidative stress factors}

MDA levels in irritable bowel syndrome group (252.26 \pm 49.36) show significant increased $(\mathrm{P}<0.05)$ compare with apparently healthy (134.54 \pm 27.38$)$ (fig: 7). While, GSH levels show significant decreased $(\mathrm{P}<0.05)$ in irritable bowel syndrome group $(74.47 \pm 7.56)$ compare with apparently healthy (157.01 \pm 48.66 ) as show in (fig: 8).

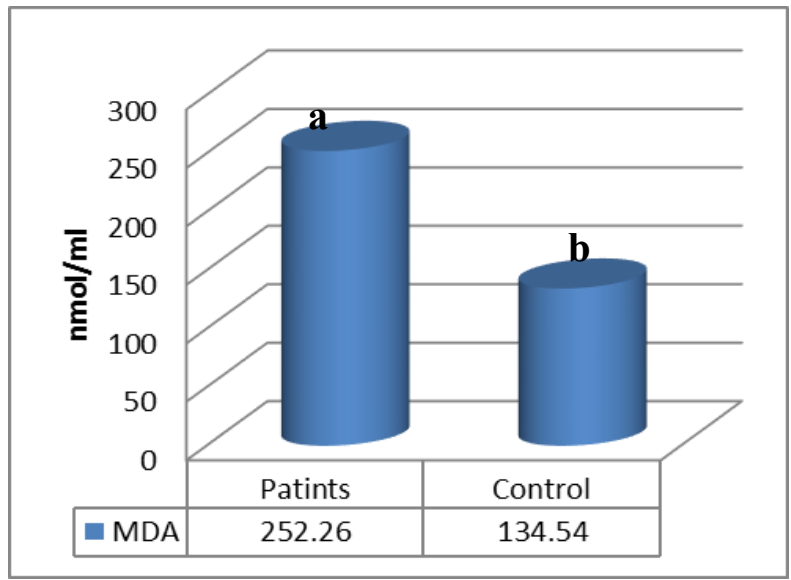

Figure (7): MDA levels in patients and healthy men groups.

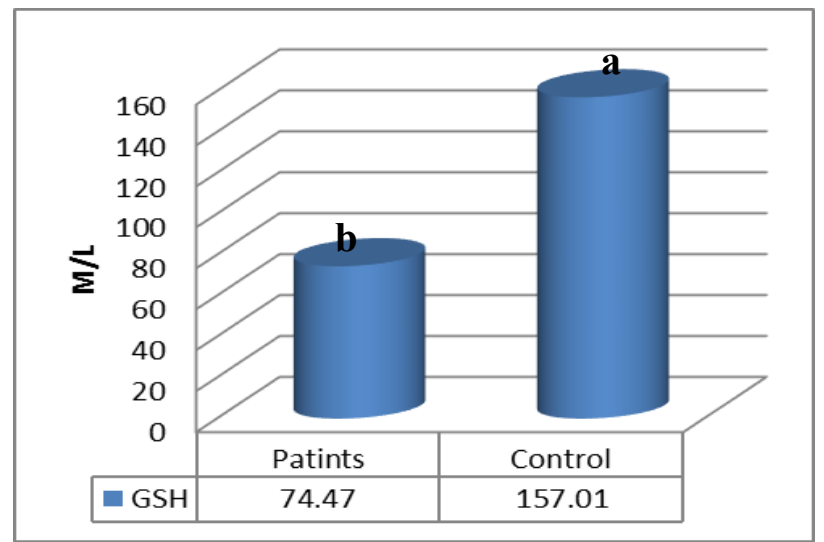

Figure (8): GSH levels in patients and healthy men groups.
Sardar et al (1996) referred that vitamin D was an antioxidant as a result of an increase in hepatic GSH amounts in rats that have gotten cholecalciferol ${ }^{[26]}$. The results of a clinical trial showed combination of vit D supplementations made a more than reduction in malondialdehyde (MDA) plasma and a considerable increase in plasma total antioxidant capacity and GSH levels compared with calcium and vit D separately (Foroozanfard et al. 2015) ${ }^{\text {[27] }}$. In other study, Baser et al. (2015) referred to the relation between vitamin $\mathrm{D}$ and oxidative stress state. They found that the total antioxidant status (TAS) levels were $1.28 \pm 0.11$ and total oxidant status (TOS) levels were $4.98 \pm 4$ $\mu \mathrm{mol} / \mathrm{L}$. in patients with vitamin D deficiency ${ }^{[28]}$ that is in agreement with the results of present study.

\section{Reference}

[1] Longstreth G.F, Thompson WG, Chey WD, Houghton LA, Mearin F, Spiller RC Functional bowel disorders. J. Gastroen. 130:1480-1491, (2006).

[2] Russo M. W.; Gaynes B. N. and Drossman D. A. (1999). A national survey of practice patterns of gastroenterologists with comparison to the past two decades. J. Clin. Gastroenterol. 29: 339-43.

[3] Drossman DA.; Camilleri M.; Mayer E.A. and Whitehead WE. (2002). AGA technical review on irritable bowel syndrome. J. Gastroen.123(6):2108-31. 
[4] Delvaux, M. Functional bowel disorders and irritable bowel syndrome in Europe. J. Alim. Pharma.Therap. 18 (3):75-9. (2003)

[5] Chang L., Review article: epidemiology and quality of life in functional gastrointestinal disorders. J. Alimen. Pharma. Therap. 20 (7): 31-9, (2004)

[6] Eckburg P. B., Diversity of the human intestinal microbial flora, Science., 308:1635-1638, (2005)

[7] Faith J.J., Guruge, J.I. and Charbonneau M., The long-term stability of the human gut microbiota., J. Sci. 5, 341 (6141), (2013)

[8] Frosali S.; Pagliari D.; Gambassi G.; Landolfi R.; Pandolfi F. and Cianci R., How the Intricate Interaction among Toll-like Receptors Microbiota and Intestinal Immunity can Influence Gastrointestinal Pathology., $J$. Immunol. Res., 489821: 1-12, (2015)

[9] Beth, D.; Robert, G. and Trap, p., Basic and clinical biostatistics, $4^{\text {th }}$ ed. Lange Medical Books/ McGraw-Hill Medical Publishing Division., New York, PP: 83-154, (2004)

[10] Sprake, E.F.; Grant VA. And Corfe, B.M., Vitamin D3 as a novel treatment for irritable bowel syndrome: single case leads to critical analysis of patient-centred data., BMJ Case Rep. 223-227, (2012)

[11] Vestergaard, P., Bone loss associated with gastrointestinal disease: prevalence and pathogenesis. Eur J. Gastro. Enterol. Hepatol., 15 (8): 851-856, (2003)

[12] Holick, M.F., Vitamin D status: measurement, interpretation, and clinical application., J. Ann Epidemiol. 19 (2): 73-78, (2009)

[13] Nwosu, B.U.; Maranda, L. and Candela N., Vitamin D status in pediatric irritable bowel syndrome., J. PLoS, 12 (2): 1-13, (2017)

[14] Khayyat, Y. and Suzan A., Vitamin D Deficiency in Patients with Irritable Bowel Syndrome: Does it Exist., J. Med., 30 (2): 115-118, (2015)

[15] Wortsman, J.; Matsuoka LY.; Chen TC.; Lu Z. and Holick MF., Decreased bioavailability of vitamin D in obesity., Am. J. Clin. Nutr, 72: 690-693, (2000)
[16] Steger, F.L., (2013) Associations between vitamin D status and blood lipid parameters in healthy, older adults. Thesis of master of science. Iowa State University.

[17] Ponda M.P.; Huang X.; Odeh MA.; Breslow J.L. and Kaufman, HW., Vitamin D May Not Improve Lipid Levels A Serial Clinical Laboratory Data Study., J. Circul. 126 (3): 270-277, (2012)

[18] Spring, T., (2016) Association between vitamin D status and long-term changes of lipid profile in healthy and younger adults. Thesis of master.

[19] Zittermann, A., Vitamin D supplementation enhances the beneficial effects of weight loss on cardiovascular disease risk markers., Am. J. Clin. Nutr., 89 (5): 1321-7, (2009)

[20] Skaaby, T., Vitamin D status and changes in cardiovascular risk factors: a prospective study of a general population., J. Cardiology, 123 (1): 62-70, (2012)

[21] Arunabh, S.; Pollack, S.; Yeh, J. and Aloia, J.F., Body fat content and 25-hydroxyvitamin D levels in healthy women., J. Endocrine. Metab. 88 (1): 157-161, (2003)

[22] McKinney K.; Breitkopf, C.R. and Berenson, A.B., Association of race, body fat and season with vitamin D status among young women: a cross-sectional study., $J$. Clin. Endocr. 69 (4): 535-541, (2008)

[23] Ortega, R.M.; Lopez-Sobaler, A.M.; Aparicio, A. and Bermejo, L.M., Vitamin D status modification by two slightly hypocaloric diets in young overweight/obese women., J. Inter. vitamin. Nutr. 79(2):71-78, (2009)

[24] McGill, A.T.; Stewart, J.M.; Lithander, F.E.; Strik, C.M. and Poppitt, S.D., Relationships of low serum vitamin D3 with anthropometry and markers of the metabolic syndrome and diabetes in overweight and obesity., J. Nutr., 7: 1- 4, (2008)

[25] Parikh, S.J.; Edelman, M.; Uwaifo, G.I.; Freedman, R.J.;Semega-Janneh, M.; Reynolds, J. and Yanovski, J.A. The relationship between obesity and serum 1,25dihydroxy vitamin $\mathrm{D}$ concentrations in healthy adults. J. Clin. Endocrino. Meta., 89 (3): 1196-1199, (2004) 
[26] Sardar S.; Chakraborty A. and Chatterjee M., Comparative effectiveness of vitamin D3 and dietary vitamin $\mathrm{E}$ on peroxidation of lipids and enzymes of the hepatic antioxidant system in Sprague--Dawley rats., Int J VitamNutr Res. 66: 39-45, (1996)

[27] Foroozanfard F.; Jamilian M.; Bahmani F.; Talaee R.; Talaee N. and Hashemi T., Calcium plus vitamin D supplementation influences biomarkers of inflammation and oxidative stress in overweight and vitamin D- deficient women with polycystic ovary syndrome: a randomized doubleblind placebo-controlled clinical trial., J. ClinEndocrinol. 83:888-894, (2015)

[28] Baser, H.; Ummugulsum C.; Salih B.; Bahauddin T. H.; Uysaler A.; Ilker B. and Fatma H. Y., Serum total oxidant/anti-oxidant status, ischemia-modified albumin and oxidized-low density lipoprotein levels in patients with vitamin D deficiency., J. Arch Endocrinol Metab. 59 (4):318-24(2015) 


\section{تقييم مستوى فيتامين D و عدد من المعايير الكيموحيوية في المرضى المصابين بمتلازمة القولون العصبي في مدينة كركوك المعائر}

فاطمة مصطقى علي'، وداد محمود لهمود العبيدي ' و عبد الحليم سالم التميمي rا (قنسم علوم الحياة، كلية العلوم، جامعة تكريت، العراق و "قَسم علوم الحباة، كلية

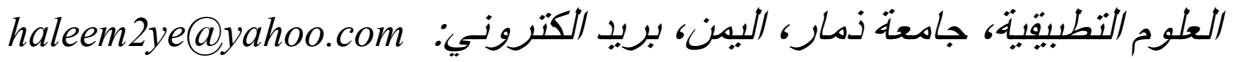

الخلاصة: صمدت الدراسة الحالية لتوضيح العلاقة بين متلازمة القولون العصبي وتركيز فيتامين Dا تم سحب الدم من • ؛ شخص مصاب يعاني من متلازمة القولون العصبي بالإضافة الى 20 منطوع سليم (معدل

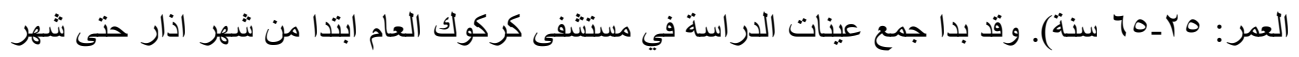

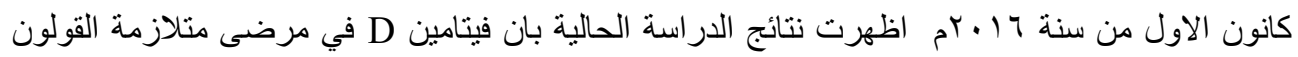
العصبي قد انخفض معنويا (P<0.05) مقارنة مع المتطوعين السليمين. ايضا اظهرت مسنويات الكالسيوم انخفاض معنويا (P<0.05) مقارنة مع المتطوعين السليمين. كما واظهرت مستويات الدهون ارتفاع معنين

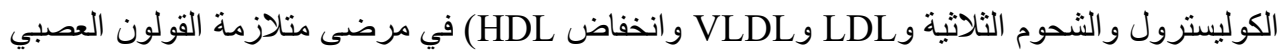
ارتفاعا معنويا (P<0.05) مقارنة مع المتطوعين السليمين. يستتنج من هذه الدراسة بان متلازمة القولون

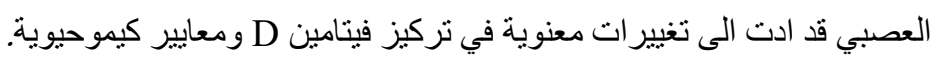

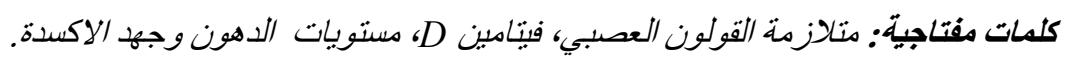

